Uğur Ümit Üngör

\title{
PROPERTY AND FAMILY
}

\author{
Mobilisation for violence during the Armenian genocide
}

\begin{abstract}
The field of Armenian genocide studies is rapidly developing, the publication of several monographs in the past 5 years having covered important new ground on the organization of the mass violence, the international context of imperialism and nationalism, and rescue efforts. Less is known on how the organising perpetrators succeeded in mobilising the foot soldiers for the violence. This article explores how the dispossession of Armenians served the interests of ordinary Turks and thus served as a catalyst for mobilisation. It also examines how local notables functioned as intermediaries in this process by eliminating competition and solidifying family ties. These local notables participated in the destruction of their Armenian neighbors and were rewarded by the central authorities.
\end{abstract}

\section{Introduction}

This article examines the Ottoman government's mobilisation of local state elites for violence and expropriation during the Armenian genocide. It attempts to understand how the Committee of Union and Progress (CUP) established alliances for carrying out the destruction of the Armenians. To what extent was establishing alliances with different social classes necessary for the cup's political objectives? The article will examine the interactions between central rulers and local elites because, ultimately, it is the local elites who are most influential in carrying out state policies on the ground. By local elite I understand various classes, such as landowners, commercial bourgeoisie, petty bourgeoisie, workers, and peasants. ${ }^{\text {I }}$ The article will discuss how the local Ottoman political elite in one region functioned under the central government's anti-Armenian policy of the years I9I5 to I9I7. This aspect of the issue also raises questions about the individual, institutional, and bureaucratic dimension of the confiscation of Armenian property. Which

I. M. Mann, The Sources of Social Power (Cambridge I993) 422, 444.

TIJDSCHRIFT VOOR SOCIALE EN ECONOMISCHE GESCHIEDENIS IO [2OI3] NR. 4, PP. 97-I2O 
bureaucratic structures did the cup spawn to orchestrate the dispossession of Armenians? And which local elites were complicit in that process? For reasons of feasibility, this article takes an approach that is focused enough to be manageable, and broad enough to capture the main aspects of mobilisation. Therefore, the focus will be on Diyarbekir/Diyarbakır province, as the basis for analysis of local mobilisation in this region is particularly strong. The article is based on a range of sources, including Ottoman archival documents, Armenian and Syriac memoirs, local histories, German, Kurdish, Danish, and Turkish eye-witness accounts, as well as reports by western missionaries.

The city of Diyarbekir/Diyarbakır is a flatfish-shaped walled citadel, situated on a basalt plateau nested in a meander of the Tigris river. Within the city walls, the urban structure consists of a square in the centre of town, surrounded by a bazaar and a maze of streets and alleys running criss-cross through the city. ${ }^{2}$ The city is structured in several ethnically segregated neighbourhoods, although the overlap of ethnicity and settlement was never absolute and most communities lived in mixed neighbourhoods. Diyarbekir/ Diyarbakır's houses are typically Middle Eastern: closed to the outside world with courtyards where social life transpires. ${ }^{3}$ The city lacked a central refuse collection system, waterworks, underground sewerage and other services until the I950s. Yet, foreigners travelling to the city recognised that "the streets are cleaner than those of many Turkish towns, and the houses better built." 4 Ottoman state power was exercised through the governorship, the Second Army, a court martial and one of the largest prisons of the Ottoman Empire. Maden county had copper mines and the eastern districts were known for being oil-rich, though no large-scale steps had been taken to exploit either. Much like the rest of the empire, Diyarbekir/Diyarbakır was a pre-industrial region where subsistence farming and cyclic pastoralism were the dominant economic occupations for peasants and nomads. ${ }^{5}$

The city and the region boasted a formidable diversity of ethnic and religious groups. The Ottoman Empire's millet system, the nineteenth-century innovation of religious communal macro-organisation that was partly autonomous in its decision-making, classified all subjects on the basis of their reli-

2. For a description of the city see: M. Alper, 'Diyarbakır, sa citadelle et ses remparts', in: Albert Gabriel (1883-1972). Mimar, Arkeolog, Ressam, Gezgin (Istanbul 2006) 93-109.

3. Gülay Zorer Gedik, 'Climatic Design: An Analysis of the Old Houses of Diyarbakir in the Southeast Region of Turkey', in: Architectural Science Review, 47:2 (2004) I45-54. For descriptions of daily life in Diyarbekir in the first half of the twentieth century see: M.Ş. Korkusuz, Eski Diүarbekir'de Gündelik Hayat (Istanbul 2007); Id., Bir zamanlar Diyarbekir: zamanlar, mekanlar, insanlar (Istanbul I999).

4. M. Sykes, The Caliphs' Last Heritage: A Short History of the Turkish Empire (London I9I5) 358 .

5. H. Christoff, Kurden und Armenier: Eine Untersuchung über die Abhängigkeit ihrer Lebensformen und Charakterentwicklung von der Landschaft (Hamburg I935) I9-73. 
gious identity. The three most important groups were the Turks, Armenians, and Kurds. The Ottoman Muslims, sometimes anachronistically called "Turks,", were the majority in most urban areas, for they had been occupying most administrative positions. The Kurdish population of the province can be divided into several categories: tribal versus non-tribal, Sunni versus Kizilbash (heterodox Shi'ites), and (semi-) nomadic versus sedentary. The Kurdish tribes in the region were generally commanded by a chieftain, and some large and powerful ones de facto controlled extensive territories. This was due to their ability to mobilise hundreds, sometimes thousands of mounted warriors, often to combat each other in pursuit of power, honour, and booty. Other ethnic groups were the Jews, an unknown number of Yezidis (syncretic monotheists), Zazas, Arabs, Gypsies, and Syriacs - by which I understand all Aramaic-speaking Syrian-Orthodox, Syrian-Protestant, Syrian-Catholic, Nestorian and Chaldean Christians. ${ }^{6}$

Most urban Armenians made their livings as merchants or craftsmen and in most bazaars the majority of tradesmen were indeed Armenians, some quite prosperous and politically active. But the bulk of the Armenians in the province were peasants living in large extended families (gerdastans) in villages dotting the vast countryside, especially in the Lice, Silvan, Beşiri, and Palu districts. Estimates for I9I4 of the number of Armenians in this province range between I05,000 (German Protestant missionaries), I06,867 (Armenian Patriarchate), to I24,000 (an Armenian almanac). ${ }^{7}$ From the late nineteenth century on, many Armenians began working in the textile industry, raising silkworms and producing silk. The revenue was considerable: in the I86os, the workshops consumed I5,000 kilogrammes of silk and 340 bales of cotton yarn per annum. The whole province produced 300,000 pieces of cloth per year, some of which was exported abroad. Diyarbekir/Diyarbakır's local textile producers were famous for producing shawls, handkerchiefs, and sheets. Instead of importing from Britain, the local production significantly boosted the region's economy. For example, in the second half of the nineteenth century, the volume of textile manufacturing grew more than eightfold. Local production may have been significant, but local consumption was truly vital. It was the local Turkish, Armenian, and Kurdish buyer of textile products that kept the industry running. There were hundreds of people active in the textile industry in Diyarbekir/Diyarbakır. For example, in I864 they included I80 cloth and linen sellers, I5 felt makers, 40 silk fringe makers, 6 silk winders, 7 pattern setters, 50 tailors, Io dyers, I4 cotton cleaners, 26 silk sellers and 320

6. For a discussion of Diyarbekir before I9I4 see: U.Ü. Üngör, The Making of Modern Turkey: Nation and State in Eastern Anatolia, 1913-1950 (Oxford and New York 20II), chapter I.

7. D. Mgount, Amidayi Artsakankner (Weehawken, NJ I950). 
weavers. ${ }^{8}$ Diyarbekir/Diyarbakir was also famous for its huge watermelons, specially trained carrier pigeons, lush vineyards, orchards, and tobacco. ${ }^{9}$

The social structure of Diyarbekir/Diyarbakır consisted of competing networks of rich, influential families of Muslim notables who had historically played the role of local power wielders in the city. These were, for example, the Cizrelizâde and Ekinci families, the powerful Pirinççizâde dynasty, the Yasinzâdes, the Ekinci family, the Iskender Pasha family, the Ocak family, and the Cizrelizâdes - most of whom lived in large mansions. Other important Kurdish dynasties were the Cemilpaşazâde, Hevêdan, Zazazâde. Most of these families had property in the countryside and often commuted between their region of origin and the city. Whereas the Pirinççizâde were historically close to the Ottoman state, the Cemilpaşazâde can be considered pioneers of Kurdish nationalism. ${ }^{\text {Io }}$ Many of these local elites were interconnected through familial ties: the Cizrelizâde were in-laws of the Yasinzâde, the Müftüzâde were related to and partly overlapped with the Direkçizâde, several women of the Zazazâde had married into the Gevranizâde family, the Cemilpaşazâde were relatives-in-law of the Azizoğlu, and the powerful Pirinççizâde dynasty was connected to most of these families through marital ties. ${ }^{\text {II }}$ Christians would not generally intermarry with Muslims, but interwoven in this social fabric were Armenian families too, such as the textile-producing Tirpanjians or the Dikranian bankers.

The politics of Diyarbekir/Diyarbakır city was marked by the political and economic competition between these provincial elites, which engaged in struggles over local government and markets. This competition was fuelled by latent conflict between the ethnically organised political factions. Indeed, the interethnic relations in the province before I9I4 were far from idyllic. They were frail due to the prolonged political crisis that afflicted the Ottoman Empire, and the country's sluggish economic development. Well before World War One, a Turkish nationalist by the pen name Uluğ proposed declaring an economic boycott against the "treacherous Armenians" (hain Ermeniler) in order to strengthen Muslim economic power. ${ }^{\mathrm{I2}}$ The gradual crumbling of Ottoman rule in the imperial peripheries throughout the nineteenth century was a product of the successful separatism of Christian peoples such

8. D. Quataert, Ottoman Manufacturing in the Age of the Industrial Revolution (Cambridge I994) 67-70.

9. Raymond H. Kévorkian and Paul B. Paboudjian, Les Arméniens dans l'Empire ottoman à la veille du génocide (Paris 1992) 397.

IO. H. Özoğlu, Kurdish Notables and the Ottoman State: Evolving Identities, Competing Loyalties, and Shifting Boundaries (Albany, NY 2004) I03-7.

II. Ş. Diken, İsyan Sürgünleri (Istanbul 2005) I34-5, 204-5, 209.

I2. Uluğ, 'Ermeniler', in: Türk, no.IIo (2I December I905) 2. 
as Greeks, Serbs, and Bulgarians. ${ }^{13}$ Among Ottoman Muslims, these events began to lead them to question the loyalty of all remaining Christian citizens in the Ottoman state. The hundreds of thousands of Muslim refugees from the Balkans and Caucasus who poured into the eastern provinces only added to the existing tensions between Muslims and Christians. Corrupt local authorities often ignored or tacitly approved encroachments on Armenians by these impoverished refugees. The Abdulhamid era massacres, which struck Diyarbekir/Diyarbakır on I November I895, were a major watershed in the province and brought massive destruction of human lives and property. ${ }^{\mathrm{I}}$

The Balkan Wars, too, affected interethnic relations in Diyarbekir/ Diyarbakır, even though it was far away from the direct heat of those wars. (See Emre Erol's contribution in this issue for an examination of the impact of the Balkan Wars on a Western Ottoman town). The war sparked discussions on national identity and threats against Armenians began to be uttered. What is crucial is that the Ottoman police at this stage still protected Armenians as Ottoman citizens. But this gradually changed with the crisis of August I9I4. That same month, Muslim merchants joined in seizing the opportunity of impunity to loot and set fire to the shops of Christians in the grain market. The news then leaked out that the pro-cup police chief, Memduh Bey, had "allowed Kurds and Muslims to pillage Armenian stores" (Kürtlerle müslümanların Ermeni mağazaların yağma etmelerine müsaade olunduğu). ${ }^{15}$ Memduh Bey reportedly even started the fire himself to create chaos and allow Muslim merchants to pillage. ${ }^{16}$ Widespread involvement, inaction by local authorities, and tacit approval of the pogrom by the police deeply shocked the Armenians of the city. In other words, ethnic relations in Diyarbekir/Diyarbakır were hostile and tense on the eve of the war.

\section{War}

On 25 March 19I5, the Ottoman government appointed Dr. Mehmed Reshid (Şahingiray) governor of Diyarbekir/Diyarbakır. ${ }^{17}$ When Reshid acceded to

13. J. McCarthy, Death and Exile: The Ethnic Cleansing of Ottoman Muslims, 1821-1922 (Princeton, NJ 1995).

I4. G. Meyrier, Les Massacres de Diarbekir: Correspondance diplomatique du Vice-Consul de France 1894-1896 (Paris 2000).

I5. Başbakanlık Osmanlı Arşivi (henceforth BOA), DH.ŞFR 44/234, Directorate of General Security (Ali Münif) to Diyarbekir, I3 September I9I4.

I6. V. Yeghiayan (ed.), British Foreign Office Dossiers on Turkish War Criminals (Pasadena, CA I99I) 480 .

I7. Born into a Circassian family during the Russo-Circassian wars, Reshid's family fled to the Ottoman Empire. He grew up in Istanbul, where he studied at the Military School of Medicine and joined other students to found a secret political party that would later 
the governorship of Diyarbekir/Diyarbakır province, he brought with him thirty to fifty mainly Circassian operatives of the Special Organisation - an Ottoman special forces unit under the War Department. ${ }^{18}$ Once in Diyarbekir/Diyarbakır, this militia was reinforced by convicts released from the local prison. ${ }^{19}$ This greatly fortified Reshid's effective power base beyond most Ottoman governors. Alexander Macfie rightly argued that "[i]n the provinces party bosses of one kind or another often exercised substantial control, amounting in some cases, [...] to virtual autonomy". ${ }^{\circ}$ Once installed as governor, Reshid faced a poor rule of law, a serious desertion problem, and an anxious population in Diyarbekir/Diyarbakır. The bazaar, always seen as the pulse of the city, was buzzing with rumours that Istanbul had fallen and that the Russians were steadily progressing. ${ }^{21}$ Diyarbekir/Diyarbakır was torn: Muslims feared a Russian invasion of their city with concomitant insecurities. Christians were torn between fear and hope: whereas the clergy and elderly nobility was terrified that a Russian incursion might trigger reprisals, a smaller, young nationalist generation expressed audacious beliefs that it was possible to defend themselves, perhaps even establish an independent

become the Committee of Union and Progress (CUP). The Abdulhamid regime exiled him to Tripoli in 1897 for his political activities. He made a career in the army, rose to the rank of major, and wrote a book on the 1908 constitutional revolution. However, never became as influential in the CUP as party bosses Dr. Bahaeddin Şakir or Dr. Nâzım. From I909 to I9I4, he quit the military and became district governor and mayor in several provinces between. In this period, Reshid began to radicalise and scapegoat the Christians as the reason for the Empire's erosion and defeats. By I9I4 he was thoroughly convinced that the Greeks and Armenians were abusing their ostensibly privileged economic positions and, therefore, were to blame for the Empire's depressed economy. He would have become Secretary-General of the international reform plan for the eastern provinces, but that plan was annulled by the CUP when it launched war. In I9I5 he became governor of Diyarbekir/ Diyarbakır and in I9I6 governor of Ankara. After the war, he was arrested and incarcerated in Istanbul, but with the assistance of his former clients, he escaped and lived incognito at various Istanbul addresses. Fed up with being forced to evade the law, and fearing arrest and possible execution, Reshid committed suicide when a police chief tracked him down on 6 February 1919. Hans-Lukas Kieser, 'Dr. Mehmed Reshid (I873-1919): A Political Doctor', in: Hans-Lukas Kieser \& Dominik J. Schaller (red.), Der Völkermord an den Armeniern und die Shoah: The Armenian Genocide and the Shoah (Zürich 2002), 245-280.

I8. Mehmed Reshid, Mülâhazât (Istanbul I9I9), transliterated in: N. Bilgi, Dr. Mehmed Reşid Şahingiray'in hayatı ve hâtıraları (İzmir I997) 89. According to another source, the number of volunteers Reshid employed was 20. A. Nesimî, Yllların İçinden (Istanbul I977) 39.

I9. Yeghiayan, British Foreign Office Dossiers I5I.

20. A.L. Macfie, The End of the Ottoman Empire, 1908-1923 (London I998) I28.

2I. Ishaq Armalto, Al-Qousara fi Nakabat an-Nasara (Beirut 1970). This detailed chronicle was written in I9I9 in Arabic by the Syriac priest Ishaq Armalto and provides a very valuable account of Diyarbekir province before and during the war. The book has been translated into Swedish: De Kristnas Hemska Katastrofer: Osmanernas och Ung-turkarnas Folkmord i norra Mesopotamien 1895/1914-1918 (Stockholm 2005), translated by Ingvar Rydberg. I will rely on an unofficial Turkish translation by Turan Karataş (Stockholm I993), p.22-28. 


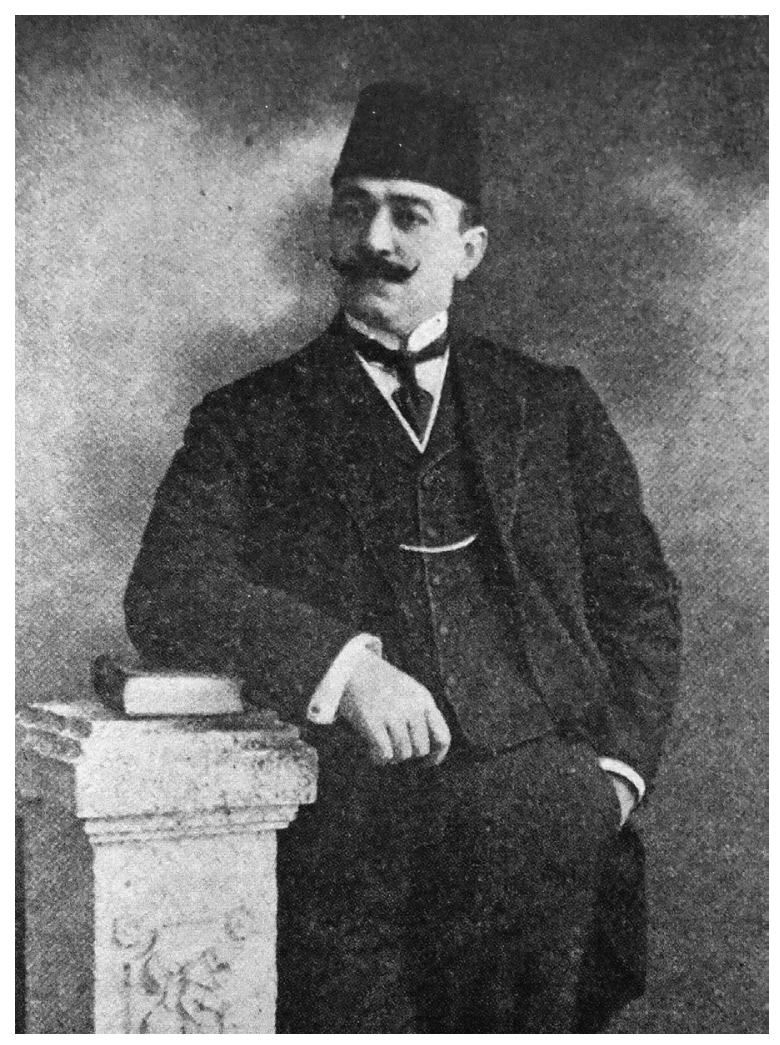

Pirinççizâde Aziz Feyzi

(1878-1933).

Source: Ottoman archives (Istanbul)

Armenia. ${ }^{22}$ Reshid's right-hand man in Diyarbekir/Diyarbakır would be his deputy Pirinççizâde Aziz Feyzi (I879-I933), a cup hardliner known for his anti-Armenian sentiments. Aziz Feyzi had often insulted and threatened the Armenian deputy Vartkes Serengulian (I87I-I9I5) in parliament. More seriously, he also had his political rival Ohannes Kazazian, a Catholic Armenian from Mardin, assassinated in I9I3. In I9I5, Aziz Feyzi would play an indispensable role in the organisation of the genocidal process, along with his cousin Pirinççizâde Bekir Sıdkı (I888-I973). ${ }^{23}$

Most young Armenian men simply wanted to avoid the possibility of being conscripted into the Ottoman army and being sent off to an almost certain death, either at the front or in the labour battalions. Some had actually gone into hiding in the complex web of rooftops of the largely Armenian neighbourhood Khanchepek, and some had acquired weapons. ${ }^{24}$ Dr. Floyd Smith,

22. Ibid.

23. Üngör, The Making of Modern Turkey, chapter 2.

24. M.Â. Tütenk, Mahsûl-i Leyâlî-i Hayatım (Diyarbekir I9I8), fourth notebook titled 'The Armenian Affair in Diyarbekir' (Diyarbekir'de Ermeni Hâdisesi) 2I-23, quoted in: Ş. 
an American doctor of the American Board of Commissioners for Foreign Missions (ABCFM), witnessed how the Armenian bishop Tchilgadian at the end of February "went upon the roofs and lectured the men, telling them that they were bringing ruin upon themselves and the whole Christian quarter. As a result quite a number surrendered." ${ }^{25}$ Still, there were a considerable number of both Muslim and Christian deserters when Dr. Reshid assumed the post of governor.

Reshid defended and sought to legitimise his wartime policies as governor of Diyarbekir/Diyarbakır in a post-war booklet simply titled "Notes." These memoirs, composed of two of his four wartime notebooks (the other two were lost), carry extraordinary importance as they allow a close look at his state of mind right after he was appointed governor. In the memoir, Reshid claims that he found confirmation of his suspicion of a widespread conspiracy of disloyal Christians, especially Armenians, whom he accuses of "high treason" and of "pursuing the goal of an independent Armenia." ${ }^{6}$ Indeed, Reshid believed that the Armenian draft dodgers on the rooftops were all "formidably" organised revolutionaries, and that they numbered more than one thousand. Moreover, according to Reshid "there was not a single Armenian in the province who was not participating in this national endeavour." 27 This was a selective rendering of the facts: Reshid ignored the even larger group of Muslim deserters, instead imagining a disciplined army of Armenians. Judging from the lack of organised Armenian defence in Diyarbekir/Diyarbakir that spring, the Armenian deserters clearly were not as numerous and organised as he imagined.

To eliminate the perceived threat, Reshid organised a committee for the 'solution of the Armenian question'. This group of men was named 'Committee of Inquiry' and had a 'Militia Unit' at its disposal. ${ }^{28}$ According to a German charity worker, the committee was drawn up of a dozen cup loyalists, was 'a sham committee for the solution of the Armenian question' that served only one purpose: to eliminate the Armenian political parties. ${ }^{29}$ It was headed by Colonel Cemilpaşazâde Mustafa Nüzhet Bey, and was manned by deputy Pirinççizâde Aziz Feyzi, postal clerk İbrahim Bedreddin, Majors Rüşdü Bey and Yasinzâde Şevki Ekinci, his brother Yasinzâde Yahya Ekinci, representative of the the Directorate for the Settlement of Tribes and Immigrants and chair-

Beysanoğlu, Anttları ve Kitabeleri ile Diyarbakır Tarihi (Diyarbakır I996), vol.2, 787-788.

25. ABCFM archives, Houghton Library (Harvard University), ABC I6.9.7, reel 716:436, Floyd Smith to James Barton, I8 September I9I5.

26. Ibid. 95, 99.

27. Ibid. I03, Io6.

28. S. Nazif, 'Doktor Reshid', in: Hadisat, 8 February I9I9.

29. Politisches Archiv Auswärtiges Amt (henceforth PAAA), RI4087, director of the Deutscher Hülfsbund für christliches Liebeswerk im Orient (Frankfurt am Main) Friedrich Schuchardt to the Auswärtiges Amt, 2I August I9I5, enclosure no.6. 
man of the Diyarbekir/Diyarbakır branch of the 'Society for National Defence' Veli Necdet, police chief Memduh Bey, militia commander Şevki Bey, and Müftüzâde Şeref Uluğ. On the orders of Reshid they appointed a few other shop owners, officials, and various other men. The mobilisation process ran along blood lines: Aziz Feyzi immediately recruited his cousin Pirinççizâde S1dk1 Taranc1..$^{\circ}$ On 6 April I9I5, the central government issued Reshid the order to "appoint a capable, loyal, and devout İttihadist for the vacant position of mayor" in Diyarbekir/Diyarbakır. ${ }^{3 \mathrm{~T}}$ The position was not vacant. Reshid fired the moderate and conciliatory Cemilpaşazâde Dr. Fuad Bey and replaced him, upon Aziz Feyzi’s suggestion, with Pirinççizâde Sıdkı Taranc1..$^{32}$

Reshid then embarked on a campaign to find and punish enemies of the Cup in the city. On I April he issued a proclamation demanding the surrender of all arms to the police. 33 When this failed to produce the results he had expected, he brutalised the arms searches from 5 April on. Together with his gendarme commander, Major Rüşdü, he personally supervised the warrantless searches of churches and houses. ${ }^{34}$ Whereas district governor Hilmi in Mardin was visiting the Christian clergy to congratulate them on Easter, 35 Reshid's persecutions became increasingly categorical. He wrote: "On a certain day I had the three or four most important streets in the Armenian neighbourhood barricaded and ordered surprise searches on every single house in the early morning, arresting more than 500 armed deserters." 36 By 15 April Reshid had already had more than 600 Armenian notables and artisans arrested and incarcerated. He had them tortured to exact confessions on the locations of hidden arms depots. The prisoners were beaten, burnt with hot irons, had their nails pulled out with pliers, and suffered prolonged bastinado. ${ }^{37}$ But Reshid was still not satisfied with what he had accomplished, so he wired Istanbul twice to request the deployment of more manpower to assist his force of 300 gendarmes and policemen. The Interior Ministry did not comply with his requests, which frustrated him and galvanised him into more severe measures..$^{8}$

30. Beysanoğlu, Diyarbekir Tarihi, 793-794; Bilgi, Dr. Mehmed Reshid, 26-27. See also: J. Naayem, Shall This Nation Die? (New York I92I) I82-I83.

3I. BOA, DH.ŞFR 5I/220, Talaat to Diyarbekir, 6 April I9I5.

32. Reshid, Mülâhazât Iı2.

33. Floyd Smith to James Barton, I8 September I9I5.

34. Abed Mshiho Na'man Qarabashi, Dmo Zliho: Verhalen over de Gruweldaden jegens Christenen in Turkije en over het Leed dat hun in 1895 en in 1914-1918 is Aangedaan (Glanerbrug 2002, translated by George Toro and Amill Gorgis) 63 .

35. Armalto, Al-Qousara 29.

36. Reshid, Mülâhazât I05.

37. Qarabashi, Dmo Zliho I27.

38. Reshid, Mülâhazât I03, I04. 
Ever since he had arrived in Diyarbekir/Diyarbakır, Reshid had not distinguished much between guilty or innocent Armenians. His intensive arms searches of the first three weeks of April had delivered some results for his militia as many arms were found. It is important to note that at this point in time, it was not illegal for Ottoman citizens to bear arms; most confiscated weapons must have been hunting rifles, although certainly some were not. What is certain is that the scope of armament and the extent of its organisation were blown out of proportion and carefully staged photos were taken of the arms and the arrestees. ${ }^{39}$ On 27 April Reshid wired an elated telegram to Talaat summarising and evaluating his work:

For ten days, the pursuit of deserters has been carried out with utmost severity. As a result of yesterday's purges a significant amount of explosives, fifty bombs, lots of ammunition and various arms, and a great deal of dynamite powder was found. I20 leaders and operatives of the villages were taken into custody. Until now, in the city alone more than rooo deserters of different regions were apprehended, many of whom are party members. Searches and pursuit are continuing. ${ }^{4}$

Having incarcerated the bulk of the political elite of the Diyarbekir/Diyarbakır Armenians, Reshid's militia now targeted the religious elites. It carried out blanket arrests of priests and monks, ransacking their houses and administering beatings. The violence was becoming more extensive and intensive.

\section{Genocide}

At this stage, Talaat had assumed supervision of the deportation of an entire population. The state-orchestrated killings on the plain of Diyarbekir/ Diyarbakır in early May I9I5, had crossed a boundary as entire village populations were now targeted for massacre. Establishing the precise link of causality between these two developments is difficult, but it is possible to reconstruct some elements of its momentum. Rafael de Nogales Mendez was a Venezuelan officer in German service, operating in the Ottoman army as a mercenary. In the spring of I9I5 he had witnessed the massacres of Armenians in Van and Bitlis. He visited Diyarbekir/Diyarbakır in late June and took the opportunity to speak to Reshid in private. According to Nogales, Talaat had wired Dr. Reshid a telegram containing a mere three words: "Burn - Destroy

39. Beysanoğlu, Diyarbekir Tarihi 789 .

40. Reshid to Talaat, 27 April I9I5, quoted in: H. Yıldırım, Rus-Türk-Ermeni Münasebetleri (1914-1918) (Ankara 1990) 57. By "party members" Reshid refers to the Armenian-nationalist Dashnaktsutiun party. 
- Kill" (Yak, Vur, Öldür). Although this order was most probably destroyed (assuming it existed at all), there was no instruction for Reshid to desist. Moreover, Reshid admitted himself that he had merely obeyed the orders of Talaat's, who had allegedly confided to him, "j'assume la responsabilité morale et matérielle." $4 \mathrm{I}$ This reconstruction is not unlikely or implausible, and does not clash with more established facts on the initiation of the Armenian genocide.

The consequences of the central government's fiat accelerated the destruction process. By the end of May I9I5, Dr. Reshid had imprisoned the entire Armenian elite of that city, where some had already died under torture. Now, Reshid felt he had carte blanche. On Sunday 30 May I9I5 his militiamen handcuffed 636 notables including the Armenian bishop, and led them through the Tigris Gate. On the shores of the Tigris the men were embarked on 23 large Tigris rafts on the pretext that they would be relocated to Mosul. Philibos Arpiarian, provincial director of the Ottoman Agricultural Bank, had worked in Kharpert/Harput, Trebizonde/Trabzon, and happened to be stationed in Diyarbekir/Diyarbakır when he was arrested in May I9I5. When he received notice that he would be deported, he sent the following letter to his family:

\section{My Dears,}

What is going to become of us is now clear. I will probably be sent toward Mosul, together with all my compatriots. Now it is left for you to be brave and endure every difficulty. What can we do? Fate brought us to this. Only continue to pray for us.

As for my journey, bring me one of the boy's sheets, a small rug, pillow, and two or three underclothes. My blue jacket and vest. In addition to this, my summer jacket, trousers, and whatever else is suitable to wear. I must not forget, also, a lot of cheese, choerag, and prepare a box of halvah.

Use your judgement and put all this together in the best way you can. Give these to Haji Garabed so he can bring to me. He is our servant. Bring a cognac bottle filled with oghi (raki) with you so you can pass it secretly to me. Do not be too late. All of you come so that I can see you for the last time.

Kisses to you, your father... Philibos Arpiarian ${ }^{42}$

Arpiarian was placed on a raft and taken away with the other notables; the goods his family sent him never reached him but were stolen by the militia. Militiamen sailed the rafts downstream to the Raman gorge, where they were moored by the left bank of the river near the villages of Shikefta and Bezawan. There, the victims were robbed of a total of 6,000 Turkish pounds, taken away in batches of six, stripped of their clothes and valuables, and massacred by Kurdish tribesmen recruited by Reshid. All men were murdered with axes,

4I. R. de Nogales, Four Years Beneath the Crescent (London 2003) I25.

42. M. Tashjian-Quiroga, The Tragic Years Remembered 1915-1920 (Troy, NY 2002) 67. 
daggers, and rifles, and dumped in the river with stones stuffed into their stomachs to make the bodies sink. ${ }^{43}$

Among the 636 victims were Onnik Kazazian, a wholesaler from Istanbul who happened to be visiting Diyarbekir/Diyarbakır, and his friend Artin Kassabian, the former interpreter of the French vice-consulate. Also killed were the noted bankers Khatchadur Dikranian and the Tirpandjian brothers, as well as master coppersmith Sarkis Tchooljian. ${ }^{44}$ The same fate befell Mihran Basmajian, graduate of Euphrates College in Kharput, Dikran Chakijian, and Nalband Hagop, all of them Dashnak party members, as well as Hagop Hovsepian, Stephan Matossian, former provincial interpreter and secondary school teacher Dikran Ilvanian, member of the municipal council and representative of Singer Missak Shirikjian, all of them members of the Ramgavar party. ${ }^{45}$ The slaughter was fast and profound: the entire Armenian elite of Diyarbekir/Diyarbakır was wiped out within a week. To the dismay of Walter Holstein, the German vice-consul at Mosul, a week later the rafts arrived empty. Holstein later found out that the convoys had been "completely slaughtered" (sämtlich abgeschlachtet) and he had witnessed their corpses floating downstream: "For several days, corpses and human limbs have been floating down the river here." 46

Having eliminated the Armenian elite of Diyarbekir/Diyarbakır, Reshid expanded the violence to genocidal proportions, as the rest of the Diyarbekir/ Diyarbakır Armenians were now targeted categorically. On I June he ordered his militia to evacuate ro6o Armenian men and women from out of the Armenian neighbourhood Khanchepek and escort them to the Diyarbekir/ Diyarbakır plain through the Mardin Gate. The Armenians were gathered and a proclamation was read out loud, offering them their lives in exchange for conversion to Islam. Although the decision does not seem to have been unanimous, the victims refused, whereupon they were stripped of their clothes and belongings. The militia and local Kurdish villagers then massacred them with rifles, axes, swords, and daggers. In the ensuing chaos, many women were raped, and some were carried off as slaves to the highest bidders. The corpses were either thrown in wells or trenches, or left on the plain to rot, "the men on their stomachs, the women on their backs." 47 After this, it was a matter of finishing the job. On I4 June I9I5 Talaat issued the following

43. Ibid.82-84; T. Muggerditchian, Dikranagerdee Nahankin Charteru yev Kurderou Kazanioutounneru (Cairo I9I9) 95-I00; Qarabashi, Dmo Zliho I28; Épisodes des Massacres Armèniens de Diarbekir: Faits et Documents (Constantinople I920) 28-30.

44. Report of M. Guys to the French embassy, Istanbul, 24 July I9I5, in: Arthur Beylerian (ed.), Les grandes puissances, l'empire ottoman et les arméniens dans les archives françaises (19141918): recueil de documents (Paris I983) 48, document no.58.

45. Muggerditchian, Dikranagerdee 95-100.

46. PAAA, Botschaft Konstantinopel I69, Holstein to Wangenheim, Io June I9I5.

47. E.W.C. Noel, Diary of Major E. Noel on Special Duty in Kurdistan (Basra I9I9), IIO-III. 
deportation order for all Diyarbekir/Diyarbakır Armenians: "All Armenians living in villages and towns of the province, will be resettled to Mosul, Urfa and Zor, with no exceptions. Necessary measures will be taken to secure their lives and property during the deportation." ${ }^{8} 8$ At the same time, the Directorate for the Settlement of Tribes and Immigrants (їмм M) ordered the "documentation of the names and places of the Armenian villages, the number of deportees, and the abandoned property and ploughland." 49

\section{Confiscation and expropriation}

On I July, the cup ordered the establishment of a Commission for Diyarbekir/ Diyarbakır, appointing two officials..$^{\circ}$ An additional order indicated that the local Muslim population was not to meddle in the property affairs in any way. ${ }^{\text {II }}$ Reshid quickly subordinated the two men and coordinated the organised dispossession. The network of patrons and clients in the militia was involved in the scheme as well. For example, as the banker Tirpanjian was tortured in prison, Veli Necdet took possession of his house and remained there throughout the war..$^{2}$ Police chief Memduh Bey stole the sum of 50,000 Turkish pounds in the persecutions. ${ }^{53}$ Another official, İbrahim Bedreddin, who later became district governor of Mardin, would send emissaries to retrieve valuable documents stolen by Kurds. Since the illiterate tribesmen had no resources or connections to redeem financial documents such as insurances, cheques and other valuables, these were to be delivered to the authorities. ${ }^{54}$ Churches and houses of rich Armenians were converted to military hospitals, ammunition depots, state orphanages, or mosques. The large Armenian church Surp Giragos functioned as a depot from where the confiscated goods were distributed. All inventories such as carpets, curtains, silverware, clerical clothing, closets, and even sacraments were sold or carried off by policemen

48. BOA, DH.ŞFR 54/87, Talaat to Trabzon, Mamuret-ul Aziz, Sivas, Canik, and Diyarbekir, 2I June I9I5.

49. BOA, DH.ŞFR 54/15, Interior Ministry to Adana, Haleb, Erzurum, Bitlis, Van, and Diyarbekir, I4 June I9I5.

50. BOA, DH.ŞFR 54/273, Interior Ministry to Diyarbekir, I July I9I5. Four days later, the Commission was established. BOA, DH.ŞFR 54/307, 5 July I9I5.

5I. BOA, DH.ŞFR 54/IO6, Interior Ministry to the Chairmen of the Abandoned Property Commissions of Erzurum, Diyarbekir, Der Zor, Aleppo, İzmit, Kayseri, and Maraş, 22 June I9I5.

52. Yeghiayan, British Foreign Office Dossiers 42.

53. Noel, Diary of Major E. Noel II.

54. Marie-Dominique Berré, "Massacres de Mardin”, in: Haigazian Armenological Review I7 (I997) 98. 
and gendarmes. ${ }^{55}$ Feyyaz Al-Husayn witnessed the confiscation process when he was sent to Diyarbekir/Diyarbakır:

You might see a carpet, worth thirty pounds, sold for five, a man's costume, worth four pounds, sold for two medjidies, and so on with the rest of the articles, this being especially the case with musical instruments, such as pianos, etc., which had no value at all..$^{6}$

Obviously, problems and irregularities arose in the implementation of the confiscations. For example, the provincial authorities queried the Interior Ministry about the procedures to follow in the case of sown fields. After some deliberation, the Ministry ordered that the Abandoned Properties Commission should harvest the fields, deduct its costs from the general revenue, and transfer the rest of the amount to the army. 57

One of the most telling examples of the dispossession policy in Diyarbekir/Diyarbakir was the fate of Tirpanjian's silk factory, which provided work for dozens of employees, mostly Armenians but also Syriacs. Silk was woven, dyed in various colours, and processed into regional clothing, characteristic for the city. Lütfü Dokucu (1924-2008) was the grandson of one of the employees. His grandfather was killed by the militia when it raided the factory, rounded up the employees, executed them outside the city walls, and threw their bodies into the river. For the rest of his life, Dokucu was forced to passively watch the Müftüzâde family lay their hands on the factory and exploit it in the decades after the war..$^{8}$

After these series of massacres, the remaining Armenians were mostly women, children, and the elderly, although some men were still alive as well. On 2 July, a convoy of 600 men was taken away and massacred just outside the city walls. Before sending the victims down the Mardin road to the valley, İbrahim Bedreddin and Memduh resorted to large-scale extortion. On I3 July, Memduh negotiated with the families of the Armenian men still in custody about a ransom, which amounted to several hundreds of Liras per family. But the men were still sent off and killed on the Diyarbekir/Diyarbakır road. 59

55. Qarabashi, Dmo Zlihorzo-I.

56. F. Al-Ghusayn, Martyred Armenia (London I9I7), 30. This memoir has been attacked as wartime propaganda, but the levels of detail in the descriptions and observations are too accurate and specific to be fabricated.

57. BOA, DH.ŞFR 54/30I, Interior Ministry to Diyarbekir, Sivas, and Mamuret-ul Aziz, 5 July I9I5.

58. Interview with Lütfü Dokucu (aged 8I) by Şeyhmus Diken in Diyarbekir in 2003, published as: "Lütfü Dokucu”, in: Ş. Diken, Diyarbekir Diyarım, Yitirmişem Yanarım (Istanbul 2003) 49 .

59. Ara Sarafian, "The Disasters of Mardin during the Persecutions of the Christians, Especially the Armenians, I9I5," in: Haigazian Armenological Review I8 (I998), 263. 
The Danish missionary nurse Hansine Marcher travelled on that road, and at some point she noticed five or six corpses laying by the roadside. Her driver said that they were "rich Armenian merchants" who had disguised themselves to prevent being deported. But the men had been detected by some drivers who had killed them and robbed them of their clothes and money. ${ }^{60}$ This suggests that the genocide created a universe of impunity: Armenians were simply seen as outlawed and fair game. Arriving in the city, Marcher walked into a café and observed the notables:

Even though Erzerum and Bitlis had fallen, and Diyarbekir lay open to the enemy, they seemed unaffected. They drank coffee, wine, etc., smoked cigarettes and let, as was customary, the fingers play mechanically with the pearls on the bead of pearls that is always to be found in the pocket of a Turk [...] The big, impressive Gregorian cathedral had been converted into an auction room. It was here that the belongings of the banished Armenians had been brought to. A number of things, e.g., linen, kitchen ware, soap, lace, jewellery, ovens, silk, pillows and blankets, honey, flour, shoe polish - everything was lying around in complete disarray and was to be sold at auction. ${ }^{61}$

All movable properties were stolen or usurped by individual state officials, whereas real estate was perched on by the Muslim notables or various state institutions. On 23 November I9I6, deportation director Şükrü Kaya ordered that even the possessions of Armenians who had not been deported, would be liquidated. ${ }^{62}$ This was another transgression that demonstrated that one escalation only invited further ones. Within half a year, all Armenians had been dispossessed, and all that needed to be brought to completion was the redistribution process.

\section{Redistribution of Armenian property}

Plundering Armenian property in Diyarbekir/Diyarbakır did not differ much from other provinces. The four main recipients of Armenian property were the ministries, the bourgeoisie, the settlers, and the army. Large buildings were used as prisons, police stations, and hospitals. For example, the central police station of Diyarbekir/Diyarbakır was twice relocated to a new loca-

6o. Hansine Marcher, Oplevelser Derovrefra (Copenhagen: KMA, I9I9) I9.

6r. Ibid. I6-I7.

62. Hilmar Kaiser, "Armenian Property, Ottoman Law and Nationality Policies during the Armenian Genocide, I9I5-I9I6”, in: Olaf Farschid, Manfred Kropp and Stephan Dähne (eds.), The First World War as Remembered in the Countries of the Eastern Mediterranean (Beirut 2006) 49-7I, at 7I. 
tion, in both cases an Armenian-owned building suitable for the purpose. ${ }^{63}$ The provincial authorities further reported that three Armenian churches in Diyarbekir/Diyarbakır could be used as prisons. ${ }^{64}$ As the state was provided for rather well in Diyarbekir/Diyarbakır, the bulk of Armenian property went to the bourgeoisie and the settlers. The Muslim settlers were to colonise the empty Syriac and Armenian villages, mostly on the Diyarbekir/Diyarbakır plain. Some were moved north and settled, others were settled on the Mardin plain. Beginning in the summer of I9I5, the settlement policy continued until the end of the war.

The settlers that were sent to Diyarbekir/Diyarbakır were Muslims who had sought asylum in the Ottoman Empire after the Balkan Wars. Many of them had lived in Istanbul in shabby dwellings, impoverished and traumatised. When World War One broke out, the cup pursued a policy of 'ethnic reorganisation' and the settlers were incorporated in it. The Albanians were but one group to be deported and settled. In June I9I5 the Interior Ministry ordered their "scattered settlement in order for their mother tongue and national traditions to be extinguished quickly." ${ }^{\text {}} 5$ The Albanians were to be settled all over the empire, including Diyarbekir/Diyarbakır province. ${ }^{66}$ The Bosnian refugees were to be settled in Diyarbekir/Diyarbakır as well. On 30 June I9I5 the Ministry ordered I8I Bosnian families temporarily residing in Konya to be deported to Diyarbekir/Diyarbakır and settled in its "empty villages" - a euphemism for Armenian land. ${ }^{67}$ The next day, the deportation and settlement of ethnic Turks from Bulgaria and Greece was ordered by the Ministry. ${ }^{68}$

As the genocide was raging in full force, the Muslim settlers were on their way. Preparations were needed in Diyarbekir/Diyarbakır in order to lodge the settlers successfully. On I7 June I9I5 the Interior Ministry reiterated its request for economic and geographic data on the emptied Armenian villages of Diyarbekir/Diyarbakır. In order to send settlers to the province, the local capacity to absorb immigrants had to be determined. ${ }^{69}$ A week later the Ministry ordered educational commodities to be provided for the settlers. This national order was a warrant for the seizure of all Ottoman-Armenian schools and their conversion into Ottoman-Turkish schools. School benches, blackboards, book cabinets and even paper and pens were allocated to the yet-toarrive settlers. The Commission for Abandoned Properties was assigned the

63. BOA, DH.EUM.MH I25/72, 5 April i9ı6.

64. BOA, DH.MB.HPS 49/3I, Diyarbekir province to Interior Ministry, I May I9I6.

65. BOA, DH.ŞFR 54/2I6, Interior Ministry to Konya, 28 June I9I5.

66. BOA, DH.ŞFR 54/246, Interior Ministry to Diyarbekir, 6 June I9I5.

67. BOA, DH.ŞFR 54/246, Interior Ministry to Konya, 30 June I9I5.

68. BOA, DH.ŞFR 54/246, Interior Ministry to Diyarbekir, I July I9I5.

69. BOA, DH.ŞFR 54/39, Interior Ministry to Diyarbekir, I7 June I9I5. 
task of carrying out this operation in Diyarbekir/Diyarbakır..$^{\circ}$ In the village of Qarabash, for example, the local Armenian school was used as a state school for Turkish children. The building was of such quality that it functioned well into the I990s. ${ }^{\text {I }}$

An Armenian survivor recalled how in the late summer of I9I5 Turks were settled in Palu. Local officials saw to it that the settlers were given the best houses of the deported Armenians. ${ }^{72}$ According to a native of Palu, in the Republican period Palu town had a Zaza, a Kurdish, and a Turkish neighbourhood. The latter neighbourhood was populated by Pomaks from Thrace. ${ }^{73}$ Three weeks after the massacre of the Armenian-Syriac village of Qarabash, the Interior Ministry ordered "the settlement of the immigrants, the confiscation of movables and pack animals, and the reporting of the population settled in emptied Armenian villages." ${ }^{74}$ Colonel Cemilpaşazade Mustafa took control of Qarabash as Pomaks and Kurds were settled in that village.75 In Kabiye, all property of the autochtonous Christians was seized and assigned to the settlers: vineyards, watermelon fields, agricultural implements, and even the carrier pigeons. The few survivors who dared to return to their village were chased out by the Muslim settlers. ${ }^{6}$ Eqsor village, on the Mardin plain, became a command post for the German army in I9I7. The Germans demolished the Syriac Catholic church and built houses with its solid stones, settling Kurdish refugees from the Karahisar region in the village.77

The genocide opened a gaping hole in Diyarbekir/Diyarbakır's socioeconomic landscape. Reconstructing the agricultural infrastructure became a priority for the government. The village of Tell Ermen, the Christian population of which had been integrally massacred in July I9I5, was repopulated with Circassians and Chechens. Since the settlers already had ploughs and oxen, all they needed for subsistence farming was seed. The Ministry of War was ordered to provide the requisite seeds, distributing I,000 cups of barley and 300 cups of wheat from storage depots to the settlers. ${ }^{7}$ When the Chechen population surpassed Tell Ermen's capacity, the construction of a new village for the Chechens was ordered in September I9I8.79 These agrar-

70. BOA, DH.ŞFR 54/33I, Interior Ministry to Diyarbekir, 7 July I9I5.

7I. Research notes from a trip to Qarabash, August 2007.

72. V.M. Kitabdjian (ed.), 'Récit de Garabed Farchian, né à Palou en I9०6 ou I907', reproduced in: Yves Ternon, Mardin 1915: Anatomie pathologique d'une destruction (special issue of the Revue d'Histoire Arménienne Contemporaine 4 (2002) 288.

73. S. Yapıc1, Palu: Tarih-Kültür-İdari ve Sosyal Yapı (Elazı̆̆ 2002) 208-2II.

74. BOA, DH.ŞFR 53/242, Interior Ministry to Diyarbekir, 5 June I9I5.

75. Qarabashi, Dmo Zliho 85.

76. O. Jastrow, Die mesopotamisch-arabischen Qaltu-Dialekte (Wiesbaden I98I), vol.II, 346.

77. Ternon, Mardin 1915 I62.

78. BOA, DH.IUU E-26/9, 27 December I9ı6.

79. BOA, DH.ŞFR 9I/I97, Interior Ministry to Diyarbekir, 22 September I9I8. 
ian policies were a knife that cut both ways: they brought manpower to the labour-intensive fields, and they addressed the rampant food shortages. Settlers were generously allocated not only Armenian land, but also seeds and implements taken from the pool of confiscated property. ${ }^{80}$

Besides the agrarian factor, the CUP's pursued an ethnonationalist policy of demographic engineering to fill in the blanks. Having destroyed hundreds of thousands of Armenian peasants, the peasant population of the country needed to be replenished. At the I9I7 CUP congress, a decision was taken on (re)settling Muslims in Armenian villages, and refining the administration of the settlements. ${ }^{8 \text { I }}$ From then on, one would find specific references to agricultural policy in the Young 'Turks' deportation orders. On I4 October I9I6 the government ordered Kurdish tribesmen from Diyarbekir/Diyarbakır province deported to central Anatolia via Urfa, specifying that on arrival, the settlers were to be employed in the "farming industry" (zeriyat işleri). They were to constitute between five and ten per cent of the local population. ${ }^{82}$ Refugeesettlers who had fled the Russian occupation and had arrived in Diyarbekir/ Diyarbakır province were supposed to work on the land too. The order read that the settlers were to be provided with pack animals and ploughs, in order for them to settle down and "begin agriculture immediately." 83 Due to shortages in Diyarbekir/Diyarbakir, the government ordered potato seeds to be imported from the province of Mamuret-ul Aziz, just to the north. ${ }^{84}$

\section{Socio-economic consequences}

By the end of I9I5, the Armenian population of Diyarbekir/Diyarbakır province was thoroughly dispossessed, deported and critically reduced in numbers. On I8 September I9I5, Reshid wired a telegram to Talaat, reporting that "the number deported from the province amounts to approximately one hundred twenty thousand." ${ }_{5}$ This is the only official statistic we have, and the precise numbers are as yet unclear. According to a French priest, during the persecutions of I9I5-I9I6 a total of I44,I85 Christians disappeared, of which 58,000 Gregorian Armenians, II,500 Catholic Armenians, Io,oIo Chaldeans, 3450 Catholic Syriacs, 60,725 Jacobite Syriacs, and 500 Protestants. ${ }^{86}$ A higher estimate was calculated by a British military official, who

80. BCA, 272.74/66.23.I7, Interior Ministry to Diyarbekir, 29 March I9I8.

8I. Tanin, 2i September I9I7.

82. BOA, DH.ŞFR 69/8, Interior Ministry to Urfa, I4 October I9I6.

83. BOA, DH.ŞFR 69/235, Interior Ministry to Diyarbekir, I2 November I9I6.

84. BOA, DH.ŞFR 72/I80, Interior Ministry to Elaziz, 8 February I9I7.

85. BOA, DH.EUM 68/7I, Reshid to Talaat, I8 September I9I5.

86. Rhétoré, Les chrétiens aux bêtes! 24I-243. 
wrote that the total number of victims was made up of 45,000 Gregorian Armenians, 6,000 Catholic Armenians, 7,000 Chaldeans, 2,000 Catholic Syriacs, 96,000 Jacobite Syriacs, and I,200 Protestants - totalling 157,000 people. ${ }^{87}$ Whatever their precise numbers, the Christian population of Diyarbekir/Diyarbakır province was all but eradicated, especially as a community. From the village level to that of the neighbourhood, parish and extended family, the genocide tore up the social fabric of Diyarbekir/Diyarbakır's Armenian communities.

Philibos Arpiarian's family had been one of the most respectable and wealthy notables of Diyarbekir/Diyarbakır. After his murder, whatever was left of the family was deported and ended up in Aleppo. Their standard of life plummeted as they went from a mansion to a one-room dwelling; the Arpiarian daughter said, it was a complete reversal in their lifestyle, "from riches to poverty." The older son Arshavir ended up doing all kinds of work including sewing, handicraft and barter. The nine-year-old son Nubar worked in a bakery and was exposed to various health and safety hazards. The family ultimately became fully dependent on help from a cousin in Beirut. The Arpiarians decided to move, first to Istanbul, and in 1920 to the United States via the Holland-America Line. On I4 August 1920 they sailed into the port of New York and began a new life. ${ }^{88}$

The damage to Diyarbekir/Diyarbakır's economy was enormous: the genocide amounted to the destruction of the middle class, in some cases eradicating entire professions. A French intelligence report stated that "the mass exodus of Christians, most of whom were artisans and merchants, had created a major economic crisis in the region." ${ }^{89}$ One example is the wine production in the region: the Syriac and Armenian winegrowers had been eliminated and failed harvests only contributed to the ruination of this business..$^{\circ \circ}$ The tex-

87. Noel, Diary of Major E. Noel II.

88. Tashiian-Quiroga, The Tragic Years 99-Ioo.

89. V. Tachjian, La France en Cilicie et en Haute-Mésopotamie: aux confins de la Turquie, de la Syrie et de l'Irak (1919-1933) (Paris 2004) 260.

90. Gustav Bredemann \& Jakob Künzler, 'Über den Weinbau und die Aufbereitung der Trauben zu Wein und Traubenkonserven in Nordsyrien und Obermesopotamien', in: Archiv für Wirtschaftsforschung im Orient 4:I/2 (I9I9) 25-54. According to a regional historian, the highly-appreciated Armenian-produced red wines of Ergani could be traced back centuries. The quality was such that they were even consumed at the Kremlin. M. Üzülmez, 'Ergani'de Şarapçılık Yeniden Canlandırılamaz mı?', in: Ergani Haber Gazetesi, I6 and 23 December 2005. By I937, the local authorities had to conclude that viticulture and vine growing was effectively dead in Diyarbekir. There had been some efforts to revive the business in Çermik and Lice, but to a negligible extent. The grapes were rare, specific for wine production, and required special knowledge to grow. B. Günkut, Diyarbekir Tarihi (Diyarbakır I937) I6. A scion of the Pirinççizâde clan wrote a book about the development of the wine production in Turkey. He misrepresents the underdevelopment of viticulture in Turkey, including Diyarbekir, as a natural product of history rather than a consequence 
tile business also experienced a dramatic downfall: the popular Diyarbekir/ Diyarbakır shawl (puşi), originally woven with red cotton cloth by Armenians and Syriacs, disappeared with the disappearance of its producers..$^{9 \mathrm{I}}$ In recent years, Diyarbekir/Diyarbakır Kurds have tried to resuscitate the crafts their past Armenian neighbors had so skillfully practiced..$^{2}$

The copper industry fell into such a decline that it seemed unlikely it would ever recover. Before the war, 230 copper smiths produced an annual 65,000 to 70,000 kilos of copper in the province. "Six hundred masters and workers, all of them Christian, earned their living in this industry, which yielded a net profit of 25 to 30 per cent." After the genocide only thirty coppersmiths remained in all of the province, and production dropped to five per cent of its pre-war volume. ${ }^{93}$ Three weeks before the Ottoman defeat in I9I8, Talaat ordered all remaining craftsmen deported to Diyarbekir/Diyarbakır, where they were herded into the inner city. ${ }^{94}$ Some of these men had been exempted from destruction because of their skills, many were coppersmiths. This policy explains that, even in the I940s, there was still a small number of Christian coppersmiths and blacksmiths in Diyarbekir/Diyarbakır. ${ }^{95}$ The noted Armenian author Mıgırdiç Margosyan is a child of one of these few surviving families in Diyarbekir/Diyarbakır's Armenian neighbourhood Khanchepek. In his many books on Diyarbekir/Diyarbakır in that period, he sketches a nostalgic picture of his youth in the I940s, when he used to work in his uncle Khachador's smithy. ${ }^{6}$

The success of the smiths was obviously related to the business of copper mining itself. Armenian smiths liaised in mining and iron work through business networks with Armenians working in the mining industry, and

of Young Turk policies. N. Pirinççioğlu, Türkiye Şaraplık Üzüm Üretimi: Şarap Sanayiinin ve Dışsatımın Olanaklarının Geliştirilmesi (Ankara I983). Nowadays, the production of wine by autochtonous Syriacs and Armenians no longer exists. other than the state-produced wines in Elazı $\breve{g}$ (such as Buzbağ), the only indigenous wine left in the entire region was the Syriac brand Circis in Mardin province. However, the last Syriac winegrower Circis Yüksel was shot dead in Mardin by the Kurdistan Workers Party (PKK) on I9 September I992. Zur Lage der Christen im Tur Abdin (Linz I993) 2.

9I. Ahmet Taşğın, 'Diyarbakır'da Geleneksel Bir Meslek: Puşicilik', in: Folklor Edebiyat 35:3 (2003) 65-73; Interview with Fuat İplikçi (aged 76) from Diyarbekir, conducted in Turkish by Şeyhmus Diken in Diyarbekir (2003), published as: 'Fuat İplikçi', in: Diken, Diyarbekir 263-286.

92. A. Zaman, 'A new silk road: The return of the scarves', in: The Economist, 3I January 2008.

93. C. Issawi, The Economic History of Turkey 1800-1914 (Chicago I980) 305.

94. BOA, DH.ŞFR 92/47, Talaat to Bitlis and Diyarbekir, 5 October I9I8.

95. Seyfi Alpan, 'Diyarbakır'ın Ekonomik Hayatına Toplu bir Bakış', in: Karacadağ 2:I7 (20 June I939) II-I4.

96. M. Margosyan, Gâvur Mahallesi (Istanbul 2002) IOI-II5. Margosyan's literary themes mostly revolve around longing, ethnic competition, and urban life. 


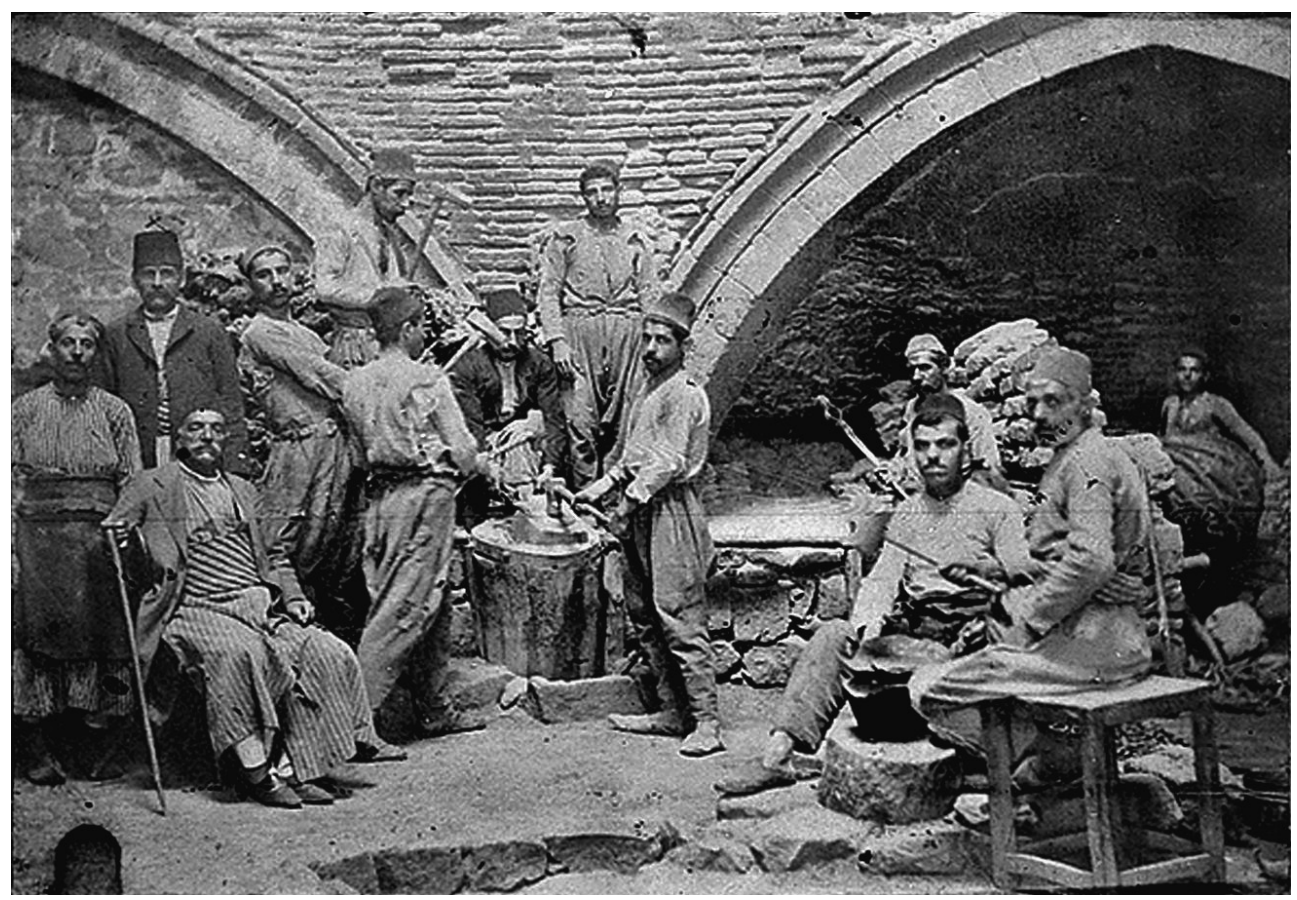

Sarkis Tchooljian, Armenian owner of a copperfactory in Diyarbekir, circa 1900

Bron: Project save Armenian Photograph Archives, Watertown, Massachusetts, usA, courtesy of John Kazanjian, grandson of Sarkis, West Orange, New Jersey.

cooperation with the Ottoman government. For example, at Ergani Maden, the Ignatiosian family was working in the industry. 97 The destruction of the Armenians in that town dictated the collapse of Maden's economy, because mining was vital to the local economy and now the copper mines were rid of almost all of their miners. Whereas Rafael de Nogales wrote around 26 June I9I5 that "the Argana-Maden mines continued normally," 98 a few months later, the Austrian military attaché Feldmarschalleutnant Josef Pomiankowski travelled through the region and lamented that because of the elimination of the Armenians "the priceless ore reserve of Argana are not exploited, and is left lying idle."99 The cup knew about the Armenian mining networks and targeted them very precisely: Talaat Pasha's notebooks mentions that a cer-

97. M.K. Krikorian, Armenians in the Service of the Ottoman Empire 1860-1908 (London I977) 72.

98. Nogales, Four Years I24.

99. J. Pomiankowski, Der Zusammenbruch des Ottomanischen Reiches: Erinnerungen an die Türkei aus der Zeit des Weltkrieges (Wien I928) 210. 
tain Khazaros Chinarian held the concessions for the copper mines at nearby Palu. ${ }^{\text {Ioo }}$ Chinarian disappeared without a trace.

A detailed economic study by Zülküf Aydın of a village in the Argana/ Ergani region follows the life and times of a Kurdish family, the Aydoğans. According to Aydın, the head of the Aydoğan family, Zakir Bey, was one of the wealthiest notables engaged in trade and moneylending. He was wellconnected to the Armenian business networks who were also engaged in trade and small-scale production. In I9I5,

some of the rich Armenians, personal friends of Zakir Bey and his trade partners, left their belongings with Zakir Bey on condition that they would get them back if they returned from wherever they were to be taken by the authorities. However, they never returned. With the expulsion of the Armenians the production of pottery and cotton cloth came to an end in the area. ${ }^{\text {IoI }}$

Having lost his networks and resources, but with some precious metals and money hoarded away, Zakir Bey took his family and moved to the town of Argana/Ergani. He was the last man standing: the destruction of the local economic intelligentsia set the province back in terms of development.

These conclusions may be extended to the entire province. The best example is probably the Pirinççizâde clan, which sustained and expanded its wealth and power due to the genocide. Aziz Feyzi had seven rather successful children: Edip, Vefik, Nezihe, Remziye, Hikmet, Kadriye and Ali Fethi (I925-2012). ${ }^{\text {102 }}$ Vefik Pirinçcioğlu (I909-I984) served as Finance Inspector, Interior Minister under İsmet İnönü's residency (I938-50), Minister of State, and Diyarbekir/Diyarbakır's member of parliament for the Republican People's Party сн р. He profited from the Wealth Tax, a thinly-disguised measure that was imposed on non-Muslims (Jews, Greeks, Armenians, Levantines). ${ }^{103}$ The consequences of this tax were large-scale dispossession and ruination of the victims, as well as property transfer whose beneficiaries were Turks. ${ }^{\text {I04 }}$ Diyarbekir/Diyarbakır Armenian families who had been dispossessed and destroyed fared ill and struggled with downward social mobility. For example, a descendant of the wealthy silk-producing Tirpandjian family was encoun-

Iо०. Bardakçı, Talât Paşa'nın Evrak-ı Metrûkesi ıо3.

IOI. Z. Aydın, Underdevelopment and rural structures in Southeastern Turkey: the household economy in Gisgis and Kalhana (London I986) I25-126.

I02. See the family tree at: http://www.pirinccioglu.com.

I03. The Wealth Tax was levied in I942 on the wealthy citizens of Turkey, with the stated aim of raising funds for the country's defence in case of an eventual entry into World War Two. However, recent research has demonstrated that the real reasons for the tax were to nationalise the Turkish economy by reducing non-Muslim influence in the country's economy. I04. F. Ökte, Varlık Vergisi Faciası (Istanbul I95I) I47. 
tered driving a taxi in New York City. ${ }^{105}$ Ottoman society lost some of its best artisans, teachers, intellectuals, economists, writers, and musicians. The French authorities in Syria kept the following list of the professions and occupations of 380 Armenians expelled from Diyarbekir/Diyarbakır province in the I920s: I tiler, 8 cobblers, 3 stonemasons, 2 pottery workers, 2 plasterers, 4 tinsmiths, I7 laborers, I dyer, 7 blacksmiths, III farmers, 5 clergy, 2 grocers, 3 carpenters, 3 millers, 2 tailors, I candle manufacturer, I goldsmith, 2 sawyers, 2 merchants, 2 bricklayers, I baker, I fitter, 3 weavers, I saddler and a latherer. The rest were women, normally housewives, mothers and peasants. ${ }^{106}$ These individuals were now lost to Diyarbekir/Diyarbakır's society.

\section{Conclusion}

Scholars of mass violence have argued that local dynamics can influence the course and intensity of genocidal processes. Local political or social elites can expedite and intensify, or delay and resist genocidal destruction steered from above. Political elites can recruit local power holders for their ends, and conversely local power holders can manipulate political elites to further their own interests. The potential of powerful local families to mobilise dozens or in some cases hundreds of potential killers can contribute to them being favoured by the centre. Mass murder can develop from this mutual dependence and tacit pact: local elites depend on the centre to secure a power base, and the centre depends on local elites to carry out genocide. This dynamic can give rise to a mobilisation process in which men participate in mass killing in exchange for economic and political benefits granted by the regime. Thus, ethnic hatred may significantly contribute but not necessarily satisfactorily explain the mobilisation of perpetrators. Rather, maintaining and increasing power for local actors can shape patterns of recruitment for and participation in genocide.

The Ottoman province Diyarbekir/Diyarbakır served as a platform for exemplifying how local dynamics shaped the Armenian genocide at the provincial level as a product of competition between families. The competition between urban elites was a major factor that contributed to the mobilisation for, and intensity of, the violence in Diyarbekir/Diyarbakır. It can also explain the levels of popular involvement in dispossession. Before the war, the main families in the city were engaged in a fierce struggle for political and economic power. Such a structural factor could easily be manipulated by the Cup dictatorship for its own ends as collaboration would be rewarded. (See Doğan Çetinkaya's article for observations on the importance of family ties to

I05. Personal communication by Richard G. Hovannisian, Los Angeles, I8 April 20 IO.

ıo6. Tachjian, La France en Cilicie 279. 
mobilisation.) The war put even more pressure on this field of competition as resources became scarcer and passivity posed a threat to one's livelihood.

This article has demonstrated how a leading family such as the Pirinççizâde emerged victorious from this competition by volunteering in the Special Organisation militias, by being more ruthless in their competitive efforts, and by actively collaborating with the campaign the cup regime deemed most urgent: the murder of their Armenian neighbours. The genocide then emerged as an opportunity for perpetrators to enrich themselves and, thereby, to solidify kin ties. When a man like Aziz Feyzi proved to be a most ruthless tormentor of Armenians, it is likely that in his eyes he was only pursuing the financial interests of his family amidst the difficult conditions of war. From his subjective perspective, the genocide evolved not as a clear evil, but rather as the shadow of virtue.

\section{Biography}

Uğur Ümit Üngör (1980) gained his Ph.D. in 2009 (summa cum laude) at the University of Amsterdam. In 2008-09, he was Lecturer at the Department of History of the University of Sheffield, and in 2009-Io, he was PostDoctoral Research Fellow at the Centre for War Studies of University College Dublin. Currently he is Lecturer at the Department of History at Utrecht University and at the NIOD: Institute for War, Holocaust, and Genocide Studies in Amsterdam. His main area of interest is the historical sociology of mass violence and nationalism. His most recent publications include Confiscation and Destruction: The Young Turk Seizure of Armenian Property (Continuum, 20II) and the award-winning The Making of Modern Turkey: Nation and State in Eastern Anatolia, 1913-1950 (Oxford University Press, 20II).

u.ungor@niod.knaw.nl 